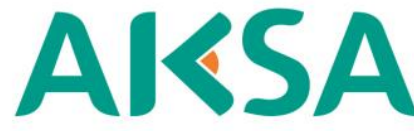

JURNAL DESAIN KOMUNIKASI VISUAL
AKSA JURNAL DESAIN KOMUNIKASI VISUAL

ISSN: 2615-1111 (online)

Available online at:

http://jurnalaksa.stsrdvisi.ac.id

\title{
Mengoptimalkan Window Ligthing untuk Foto Potret dengan Menggunakan Kamera DSLR 1000D dan 60D
}

\author{
Nofria Doni Fitri ${ }^{1}$, R Hadapiningrani Kusumohendrarto ${ }^{2}$ \\ Sekolah Tinggi Seni Rupa dan Desain Visi Indonesia \\ donifitri13@gmail.com
}

\begin{abstract}
ARTICLE INFO
ABSTRACT

Article history:

Photography is a visual language that prioritizes the role of light. In

Received: 10 Agustus photography there are several shooting formats, one of which is 2018 portrait or shooting vertically. Portrait photos are photos of a

Revised: 22 Agustus

2018 person's face that can reveal the character of the person, therefore the shooting exposure must be precise. In fact, the current portrait

Accepted: 29 Agustus 2018 photos are not optimal because they do not consider the aspects of light and the correct shooting technique. Portrait photos can easily be done using window lighting techniques. This research was

Keywords: carried out on portrait photos with window lighting techniques Window lighting

Portraits produced from two different types of DSLR cameras.

DSLR Cameras In the world of photography especially beginner photographers assume that the higher the level or class of the camera can produce better images. However, in the world of photography the results of good images are not solely produced by professional-class cameras, but by considering the exact exposure when shooting.

Through this window lighting technique, researchers hope to find the essence and formula of making portrait photos that are of good quality and can be done by DSLR camera users. A good portrait photo, besides revealing a person's character also has a strong impact power.
\end{abstract}

\section{PENDAHULUAN}

Fotografi awalnya dari seberkas sinar memproyeksikan objek masuk melalui lobang kecil ke dalam kotak yang kedap cahaya, Kotak kecil itu disebut adalah ruang yang digelapkan (kamera), di kamera diletakkan selembar kertas peka cahaya yang mampu menyimpan bayangan objek itu sementara. Image tersebut dikembangkan dengan larutan kimia, kemudian dikuatkan, akhirnya sebuah gambar tercipta di atas selembar kertas yang disebut fotografi.

Window lighting pertama kali digunakan oleh pelukis Belanda Rembrant Van Rinj, yang melukis modelnya di dekat jendela dengan memanfaatkan cahaya yang masuk melalui jendela sebagai sumber cahaya utama. Wajah model lukisannya tersebut terang sedangkan area di sekitar 
wajah berwarna hitam (gelap). Hasilnya model yang digambar seperti muncul dari kegelapan. Teknik melukis seperti ini cukup digemari pada waktu itu dengan sebutan painting with window lighting.

Teknik window lighting ini kemudian banyak pula dilakukan fotografer, di awal kamera SLR 135 buatan Jerman dengan merk Leica ditemukan, foto potret dengan pencahayaan dari jendela disebut dengan Portraiture with Window Lighting. Prinsip pencahayaan window lighting ini kemudian ditiru dengan pencahayaan lampu studio dengan biaya mahal karena harus dikerjakan di dalam studio fotografi dengan perangkat pencahayaan yang lebih lengkap. Walupun tidak perlu membawa model ke dekat jendela, namun penataan subjek dan teknik pencahayaan yang digunakan mengikuti aturan dan ketentuan di window lighting. Selain itu foto potret saat ini dibuat tanpa memperhitungkan efek cahaya, contohnya dapat ditemukan pada media publikasi cetak seperti surat kabar. Wajah seseorang dipotret di mana orang itu berada, tanpa berfikir untuk mencari tempat yang lebih baik untuk pencahayaannya. Bahkan sebagian dri mereka menggunakan flash yang berada di atas kamera sehingga gambar menjadi kehilangan dimensinya. Ketidaktahuan sebagian besar fotografer terkait teknik mengoptimalkan window lighting untuk pembuatan foto portret, menyebabkan teknik ini tidak populer di kalangan fotografer saat ini.

Potret, adalah gambaran diri seseorang, terutama bagian wajah karena mampu mengidentifikasi subjek dan membedakannya dengan subjek lain. Fotografer potret bagaikan seniman pahat yang mengolah tentang kepala dan wajah yang baik. Kesan pada wajah manusia (ekspresi) dapat merefleksikan perasaan yang sedang dialaminya. Penggunaan kamera pada fotografer terbagi menjadi dua kelas yaitu prosumer dan profesional, dimana hanya terdapat beberapa perbedaan dari fitur-fitur yang ditawarkan. Pada prinsipnya kedua kamera ini samasama memiliki fitur utama terkait sistem exposure. Kedua type kamera ini memiliki metering system untuk membaca cahaya dalam menentukan nilai exposure. Pengukuran ini sangat dibutuhkan untuk membaca pencahayaan yang jatuh pada wajah model foto potret di dekat jendela (window lighting).

Dengan adanya penelitian ini, diharapkan dapat menemukan sebuah formulasi dalam meneliti atau diagram yang tepat untuk pembuatan foto potret menggunakan teknik window lighting dengan dua type kamera DSLR yang berbeda secara optimal. Penelitian ini juga dapat mempopulerkan kembali window lighting untuk menghasilkan foto potret yang berdimensi dengan teknik exposure yang benar. Rumusan masalah yang akan menjadi acuan penelitian adalah untuk mengetahui hasil perbedaan dari dua type kamera DSLR yang berbeda untuk foto 
potret window lighting. Penelitian ini bertujuan untuk mengetahui hasil foto dari dua type kamera DSLR Canon kelas profesional yang mahal dan DSLR yang paling murah. Apakah kemampuan kedua tipe kamera ini setelah diuji dengan variabel sama terlihat perbedaan yang signifikan?

Penelitian diharapkan memberikan kontribusi pada penelitian lain khususnya di bidang fotografi. Khusunya dalam mengoptimalkan teknik window lighting untuk foto potret dengan kamera DSLR dapat membantu mahasiswa yang tidak mampu membeli kamera DSLR yang canggih dapat menggunakan kamera yang murah. Penelitian ini dapat memberikan wawasan kesadaran kepada mahasiswa terhadap dua type kamera yang berbeda pada foto potret dengan teknik window lighting. Kontribusi lainnya, diharapkan dengan penelitian ini diperoleh sebuah formula untuk teknik window lighting yang tepat untuk foto potret.

\section{METODE PENELITIAN}

Pengambilan foto potret dengan window lighting dilakukan dengan mengambil sampel penelitian terhadap model manekin yang ditempatkan di dekat jendela. Setelah penerapan variable yang ditentukan pada objek manekin, kemudian akan dilakukan pemotretan langsung pada objek orang tua lanjut usia di Daerah Istimewa Yogyakarta. Sampel model foto potret dilakukan pada bebarapa model orang tua lanjut usia.

Data yang akan digunakan sebagai bahan uji coba atau patokan dalam penelitian adalah data kualitatif yang diperoleh saat melakukan proses foto potret window lighting pada model. Prosedur proses penelitian ini dilakukan dengan melihat langsung hasil dari variabel-variabel yang telah ditentukan sebelumnya. Dari data ini diharapkan dapat ditemukannya hasil yang dapat memaksimalkan penggunaan kamera DSLR terhadap penggunanya walaupun dengan keterbatasan alat yang dimiliki.

Variabel-variabel yang digunakan dalam penelitian ini adalah jarak kamera dengan model, jarak model dengan cahaya jendela, ukuran jendela yang digunakan, waktu pengambilan gambar, serta faktor pendukung lainnya sehingga penguasaan kamera DSLR dapat digunakan secara maksimal meskipun adanya keterbatasan alat yang dimiliki.

Pengujian sampel dilakukan dengan cara mengamati proses penelitian yang telah dijabarkan pada variabel penelitian yang kemudian akan dilakukan penelitian secara terukur untuk mendapatkan hasil yang maksimal dan terbaik. Pengukuran variabel ini dilakukan pada jarak dan posisi subjek terhadap jendela dan kamera, intensitas cahaya, panjang titik api lensa, sudut pengambilan gambar, mode dan exposure value yang digunakan. 
Setelah dilakukan penelitian terhadap variabel dan pengujian dua tipe kamera terhadap foto potret dengan teknik window lighting maka langkah selanjutnya tim peneliti menganalisa dua aspek di atas. Tahap analisa ini kemudian akan menghasilkan formulasi atau diagaram pemotretan yang tepat untuk foto potret dengan teknik window lighting. Kemudian dari hasil formulasi tersebut akan diketahui perbandingan mengenai hasil foto dua type kamera DSLR yang berbeda pada foto potret dengan teknik window lighting, pembuktian ini pun akan dilakukan publikasi penelitian yaitu berupa modul ajar fotografi dasar topik window lighting untuk foto potret.

\section{PEMBAHASAN}

Pengertian foto portrait sangat luas mulai dari foto kehidupan manusia sehari-hari dengan segala aktivitasnya, hingga bentuk ciri bagian kepala hewan masuk dalam wilayah foto portrait. Namun, foto potret yang dimaksud dalam penelitian ini adalah foto wajah manusia dari kepala hingga dada yang dalam seni patung di sebut torso. Model adalah orang tua yang memiliki kerutan di wajahnya yaitu dengan usia di atas 45 tahun, pria atau wanita. Format pengambilan gambar sesuai dengan sebutannya portrait atau vertikal yaitu format meninggi dengan perbandingan 2:3 atau 3:4 mengikuti set kamera DSLR.

Penggunaan kamera pada fotografer terbagi menjadi dua kelas yaitu prosumer dan profesional, terdapat beberapa perbedaan dari fitur-fitur yang ditawarkan. Pada prinsipnya kedua kamera ini sama-sama memiliki fitur utama terkait sistem pencahayaan (exposure system). Kedua tipe kamera ini memiliki metering system untuk membaca cahaya untuk menentukan nilai exposure. Pengukuran ini sangat dibutuhkan untuk membaca pencahayaan yang jatuh pada wajah model untuk foto potret di dekat jendela (window lighting).

Selain mahal, kamera DSLR kelas profesional tidak terjangkau oleh mahasiswa dengan status ekonomi menengah ke bawah. Penelitain mencoba membuktikan bahwa kamera DSLR paling murah dapat diandalkan untuk belajar fotografi. Kamera DSLR dapat diatur komponen exposure-nya untuk menghasilkan karya fotografi yang bagus, tidak harus dengan kamera yang mahal. Langkah-langkah yang dilakukan dalam penelitian digunakan untuk mengetahui hasil perbedaan dari dua tipe kamera DSLR yaitu kamera kelas profesional dangan kamera kelas prosumer. Harga kedua kamera ini jelas terpaut jauh, artinya ada banyak kelebihan atau fasilitas yang dimiliki kamera profesional dibandingkan kamera DSLR biasa. penelitian ini menguji kemampuan kedua kamera dalam membuat potret orang tua di dekat jendela. Apakah perbedaan 
ini berpengaruh terhadap kualitas gambar akan diketahui kemudian. Untuk foto potret dengan teknik window lighting dilakukan langkah-langkah sebagai berikut.

Dalam menentukan sebuah parameter standar untuk dijadikan sebagai alat ukur (indikator) yang diujikan pada kedua tipe kamera DSLR ini adalah aspek-aspek yang fundamental dapat berpengaruh pada hasil akhir sebuah foto. Parameter ini akhirnya merujuk pada aspek kesamaan objek foto, intensitas cahaya, waktu pengambilan gambar, panjang titik api lensa, jarak objek dari jendela, dan jarak objek dari latar belakang.

\subsection{Metode Pemotretan}

Pengambilan dilakukan dengan uji coba teknik window lighting pada model manekin. Manekin (patung manusia setengah badan) diposisikan di dekat jendela sebagai model untuk menganalisa jatuhnya cahaya pada wajah model pada tiga posisi yang berbeda yaitu; Posisi 1 (di depan jendela), posisi 2 (di tengah jendela), dan posisi 3 (di belakang jendela). Pengujian analisa ketepatan jatuhnya sinar pada wajah dan bagian tubuh selain untuk menunjukkan perbedaan gelap-terang (dimensi) yang terjadi pada wajah model juga menentukan karakter dari wajah yaitu identitas orang yang difoto.

Selain mengetahui teknik pencahayaan, pemotret harus dapat mengatur pose dan ekspresi model foto untuk memperkuat karakter dan identitas model. Sumber cahaya yang digunakan adalah satu sumber cahaya yang terbiaskan masuk melalui jendela dan mengenai wajah model. Kualitas cahaya ditentukan dari lebar jendela yang akan dilalui oleh cahaya. Berkaitan dengan tingkat kontras gambar yang dihasilkan oleh cahaya dapat dibagi dua. Gambar akan kontras jika simber cahaya sempit dan kontras lemah (kekontrasan berkurang) jika sumber luas. Bila sumber cahaya lebih lebar dari objek maka, sumber cahaya tersebut akan menghasilkan kontras gambar yang lemah. Jika besar sumber cahaya lebih kecil dari lebar model maka sumber cahaya akan menghasilkan kontras yang tinggi. Sumber cahaya besar dapat terjadi bila model di dekatkan ke sumber cahaya dan sumber cahaya kecil dapat terjadi bila objek jauh dari sumber cahaya (jendela). Sumber cahaya besar akan menghasilkan efek cahaya yang lebih soft dibandingkan dengan sumber cahaya yang kecil. (Base on Cassell Camera Wise Guides, Secret of Light, Eaglemoss Publications Ltd, Australia, 1994, p.22)

\subsection{Pembahasan}

Parameter indikator yang dijadikan sebagai ukuran untuk membandingkan hasil foto dua tipe kamera DSLR adalah: Besar jendela yaitu; Tinggi jendela $120 \mathrm{~cm}$, Lebar $70 \mathrm{~cm}$, jarak sisi 
bagian bawah jendela dari lantai lebih kurang $70 \mathrm{~cm}$. Lebar manekin $17 \mathrm{~cm}$ ideal dengan postur tubuh manusia normal. Jarak manekin ke jendela: sama dengan lebar jendela (sumber cahaya besar). Jarak manekin ke latar belakang $200 \mathrm{~cm}$. Waktu pemotretan pagi, siang dan sore hari. Lengkapi dengan diagram pemotretan (denah pemotretan).

Data kamera: kamera di seting dengan under exposure 1/3, f stop karena foto window lighting lebih dominan bagian gelap di sekitar wajah (model foto). Mettering mode: spot (pengukuran memusat diarahkan pada cahaya paling kuat pada manekin). ISO/ASA: 200, diafragma/aperture (f) 4.5, shutter speed (s) 1/60 second, Lensa: 55 mm (standard) dimiliki oleh semua lensa kit.

Dimulai dari posisi 1 (objek di depan jendela). Analisa cahaya pada penelitian ini dilakukan dengan memotret objek manekin ukuran torso (close up) yang dicat dengan acrylic warna abu-abu (grey 18\%). Analisa ini bertujuan untuk menentukan nilai pencahayaan (exposure value) yang dibutuhkan sama seperti kecerahan pada kulit manusia pada umumnya. Setelah dilakukan uji coba maka terdapat perbedaan nilai exposure dari tiga posisi objek tersebut terhadap jendela. Posisi 2 (dua) mengalami penambahan jumlah cahaya yang menerangi objek. Penambahan ini mengakibatkan salah satu komponen penentu pencahayaan harus disesuaikan untuk mempertahankan pencahayaannya tetap tepat (akurat) atau (correct exp[osure). Saya mengubah angka kecepatan (shutter speed) untuk menyesuaikan pencahayaan untuk dua posisi tengah dan belakang. Kompensasi untuk penyesuaian ini adalah $1 / 3 \mathrm{f}$ stop lebih gelap. Jika correct exposure ISO 200, Shutter Speed 1/ 60 second, dan aperture 4.5 maka pada posisi 2 (dua atau di tengah jendela) untuk correct exposure-nya menjadi ISO 200, Shutter Speed $1 / 90$ second, dan aperturef/4.5. Begitu juga pada posisi 3 (tiga atau di belakang jendela) mengalami penambahan jumlah cahaya dari posisi 2 (dua) 1/3 f stop sehingga exposure value untuk posisi 3 (tiga) menjadi: ISO 200, Shutter Speed 1/160 second, dan aperture f/4.5. Diafragma (aperture) tetap dipertahankan pada bukaan terbesar yang dimiliki oleh lensa kit yaitu f/4.5 dengan tujuan untuk mempertahankan kualitas out of focus di latar belakang (tembok atau dinding rumah). 

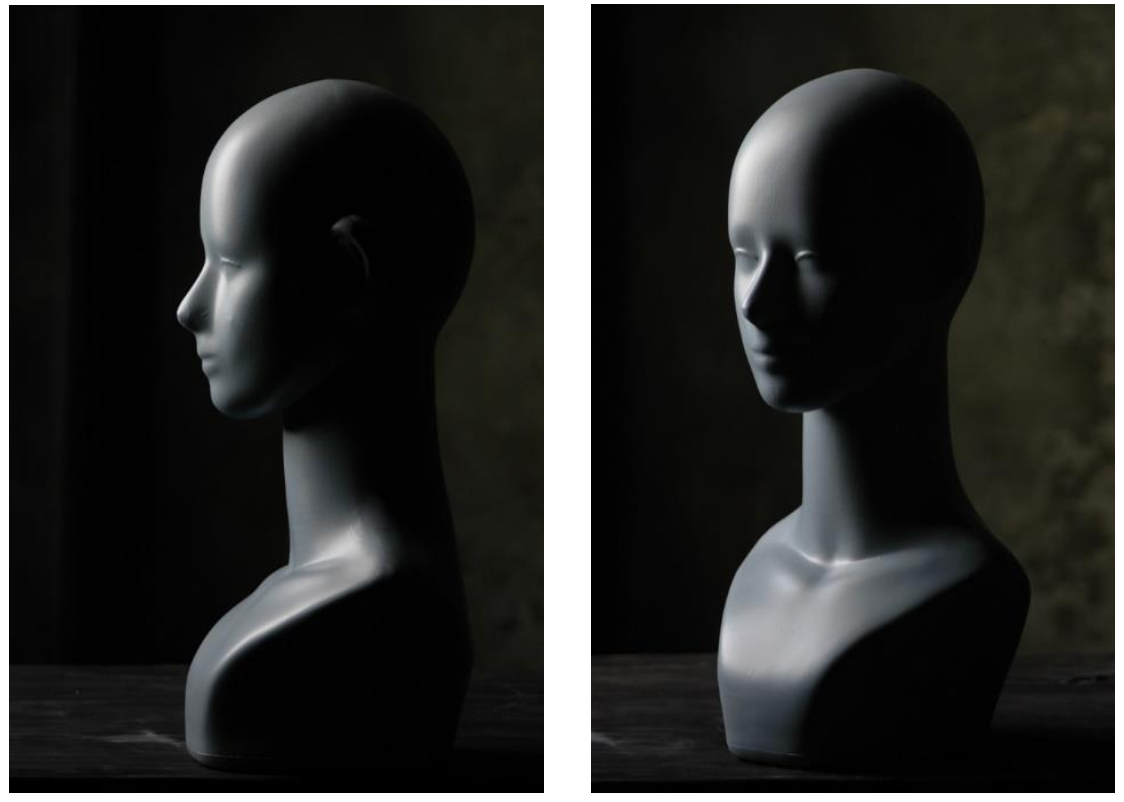

Gambar 1. Posisi 1 (di depan jendela)

Objek pada posisi 1 (di depan jendela) mutlak diarahkan ke sumber cahaya maka posisinya menghadap ke jendela dan 90 derajat di samping fotografer). Wajah manekin akan terlihat hanya dari satu sisi. Garis cahaya (rim lighting) terlihat pada hidung dan dahi manekin. Porsi terang $30 \%$ dan gelap $70 \%$.
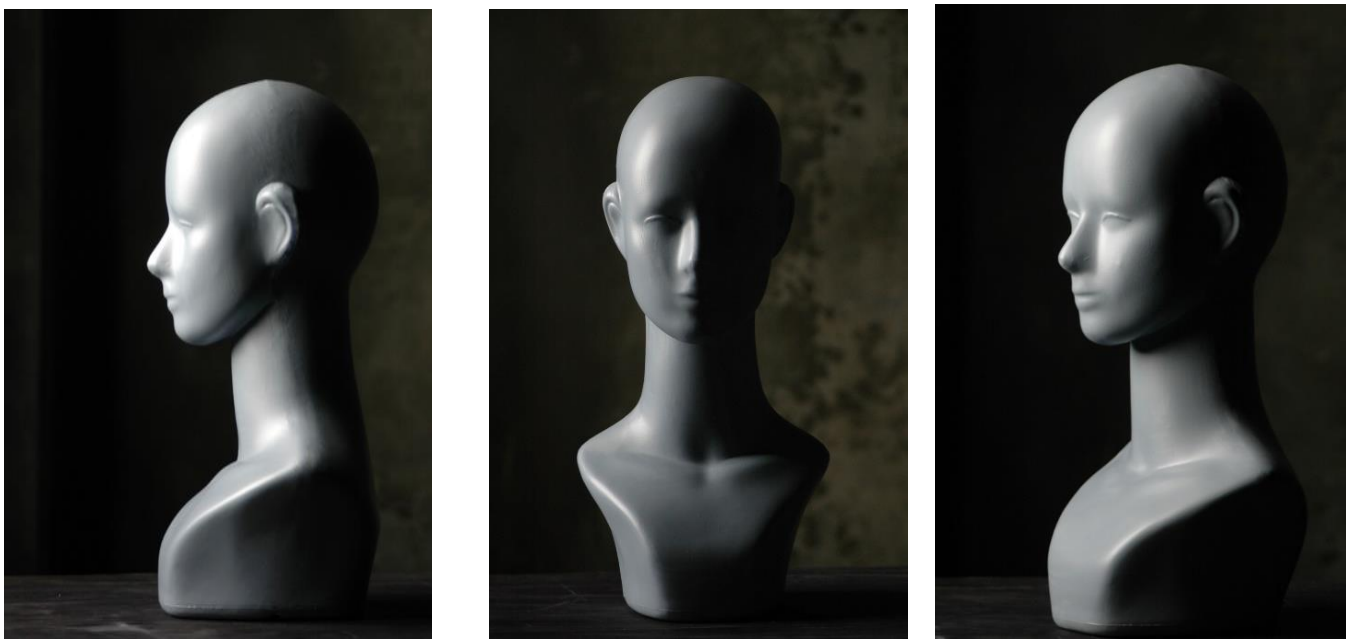

Gambar 2. Posisi 2 (di tengah jendela)

Objek pada posisi 2 (di tengah jendela) wajah model diarahkan ke sumber cahaya maka posisinya bisa dari samping atau menghadap ke jendela dengan sudut $3 / 4$, porsi terang dan gelap pada objek sama 50\%:50\%. 

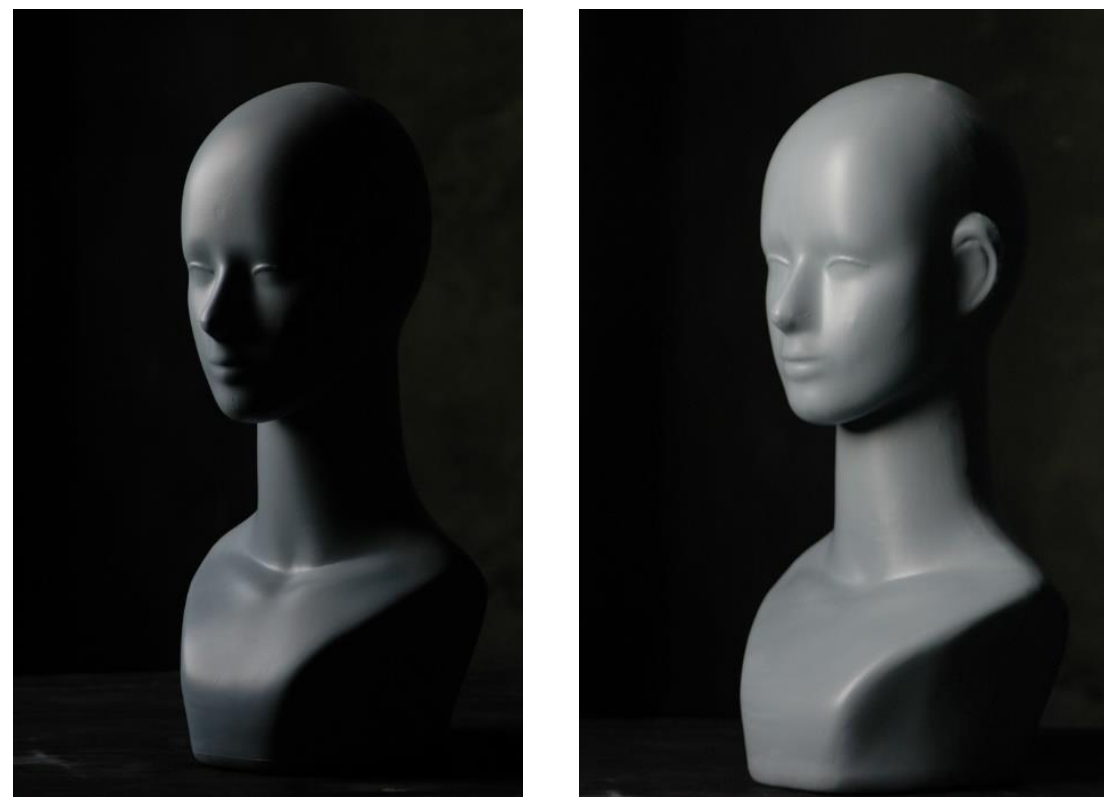

Gambar 3. Posisi 3 (di belakang jendela)

Pada posisi objek di belakang jendela akan terlihat posrsi terang pada wajah lebih dominan. Porsi terang 60\% dan gelap $40 \%$.

Dari hasil uji coba pada objek manekin, terdapat higlight, middel tone dan shadow area yang dapat diamati pada tiga posisi model. Latihan ini untuk membiasakan pemotret (fotografer) untuk jeli dalam menganalisa cahaya sebelum memotret dan menggunakan exposure metering yang tepat untuk foto orang tua. Sudut pengambilan gambar sejajar dengan kamera artinya posisi kamera setinggi objek (manekin). Cahaya matahari terbiaskan (indirect light) masuk melalui jendela. Posisi cahaya lebih tinggi dari manekin. Lebar jendela $70 \mathrm{~cm}$ dengan jarak objek dari jendela yang sama atau lebih pendek dari $70 \mathrm{~cm}$ menjadikan sumber cahaya ini sumber cahaya besar. Bila dibandingkan dengan besar objek yang hanya $17 \mathrm{~cm}$, maka sumber cahaya ini merupakan sumber cahaya yang besar sehingga kontrasnya tidak begitu tinggi. Kontras tinggi terjadi karena objek manekin berada di ruangan tanpa pencahayaan dan satu-satunya sumber cahaya yang masuk hanya dari jendela tersebut. 


\section{DIAGRAM PEMOTRETAN \\ WINDOW LIGHTING}

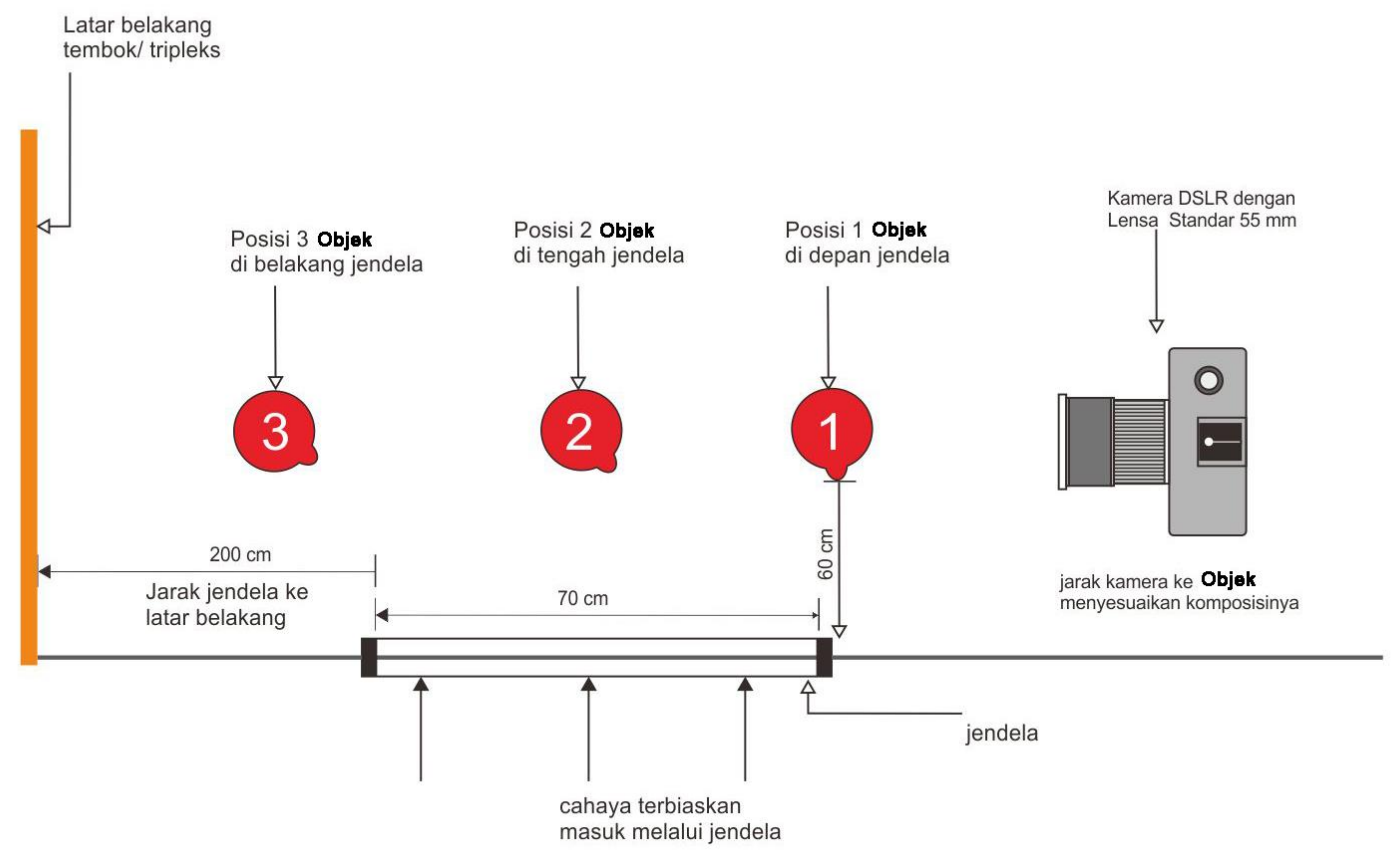

Gambar 4. Diagram Pemotretan model orang tua dengan Teknik window lighting dari dua jenis kamera DSLR Canon $60 \mathrm{D}$ dan Canon $1000 \mathrm{D}$.

Berikut adalah contoh penerapan metode penelitian pemotretan model orang tua dengan teknik window lighting dari dua tipe kamera DSLR yang berbeda dengan setting kamera yang sama. Diafragma terbesar 5,6, ASA/ ISO 200, untuk memaksimalkan kualitas butiran gambar (grein) Lensa standar 50-55 mm untuk hasil foto sesuai dengan pandangan mata (proporsional) White Balance Auto, Resolusi tinggi Large, jenis file JPEG Fine. Pemotretan untuk foto 1 - 2 dilakukan pada pagi hari, foto 3-4 pada siang hari dan foto 5-6 pada sore hari.

\begin{tabular}{|l|l|}
\hline 1 & \\
\hline Nama : & Ibu. Sarjinah \\
\hline Umur & 58 tahun \\
\hline Pekerjaan & Tidak Bekerja \\
\hline Alamat & Salulan_Pendowoharjo Bantul \\
\hline & Camera DSLR Canon 60 D \\
\hline
\end{tabular}




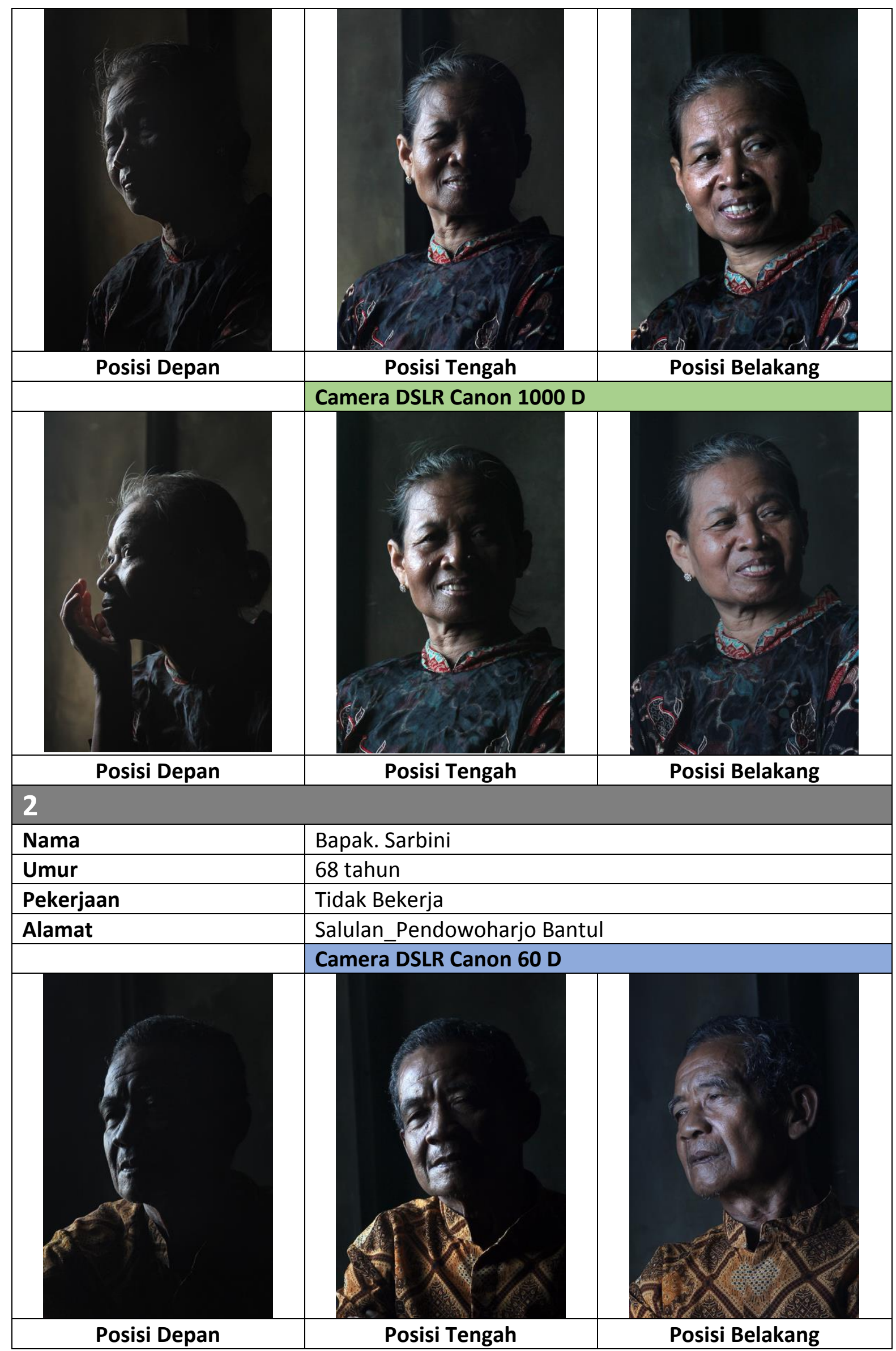




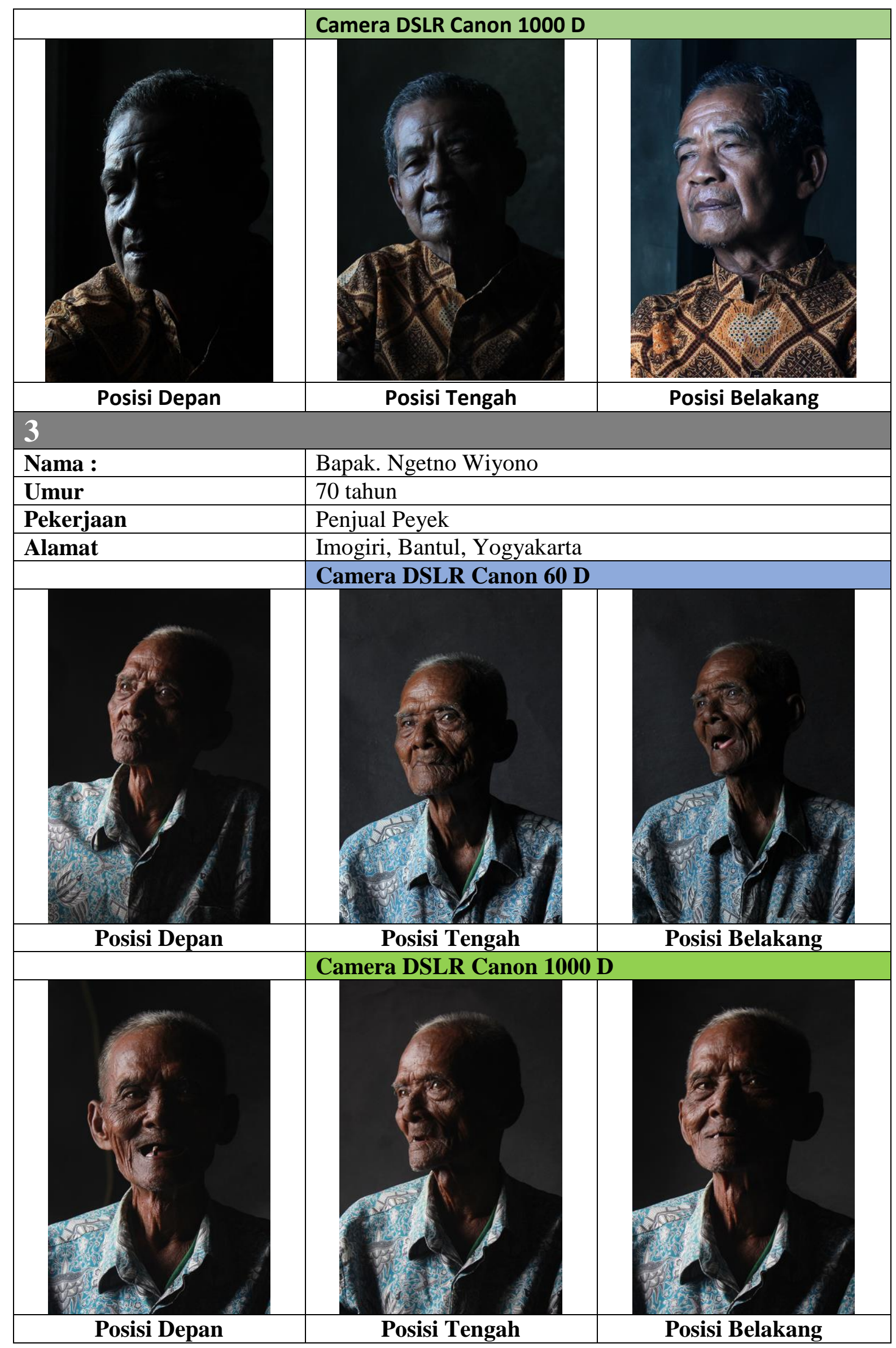




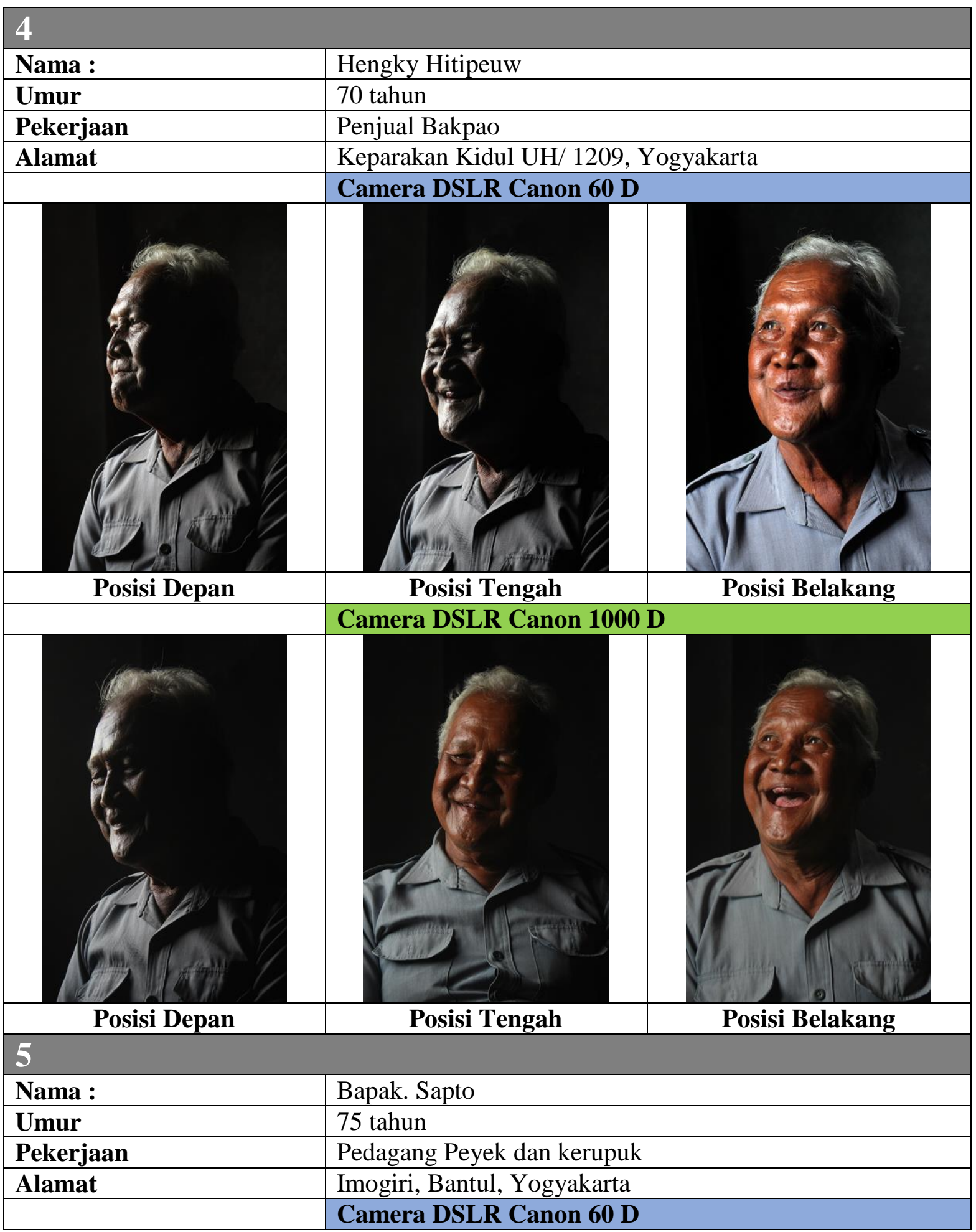




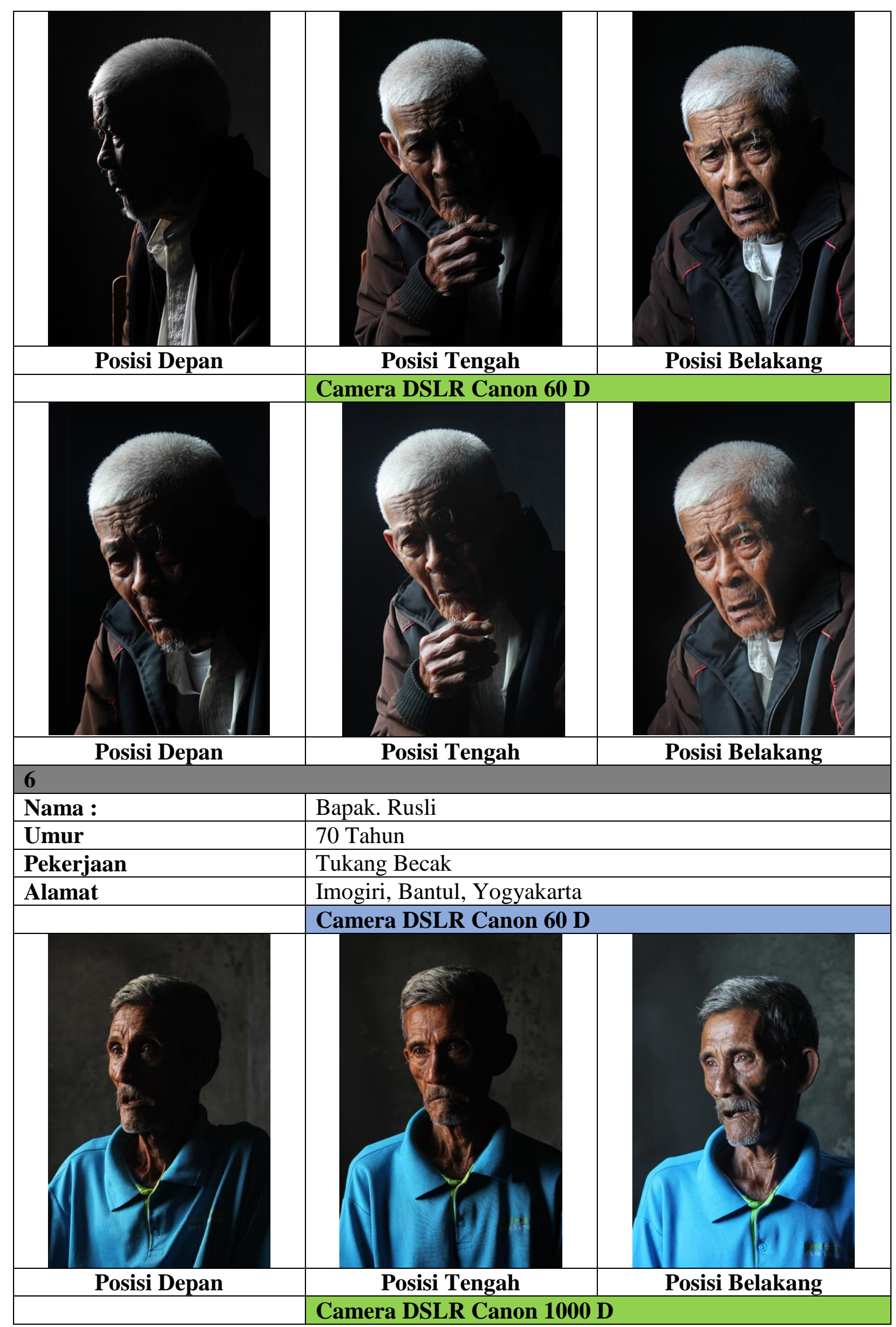




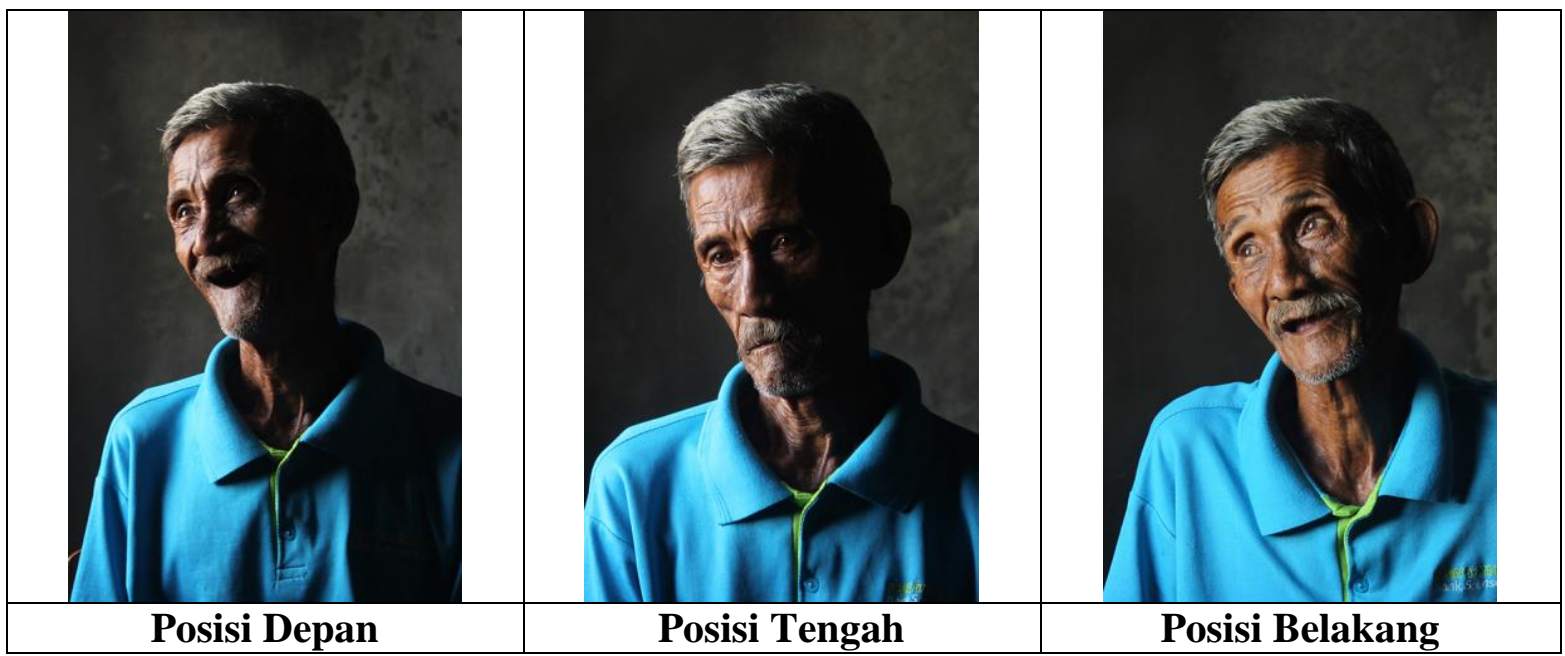

\section{KESIMPULAN}

Pembuatan foto potret dengan window lighting, posisi wajah model mutlak harus menghadap ke sumber cahaya (jendela) guna mengidentifikasi karakter wajah model. Bagian di depan objek diberi ruang yang lebih besar dari pada area di belakang objek. Supaya terlihat komposisi yang menarik dan kenyamanan dalam pandang terhadap foto. Pengukuran pencahayaan yang paling akurat terhadap model di dekat jendela adalah dengan menggunakan spot metering dengan sedikit under expose yaitu 1/3 f stop untuk mengantisipasi terjadinga over exposure pada hight light karena luas area yang dominan gelap. Pengukuran diarahkan pada bagian yang terkena cahaya paling dominan.

Membuat foto portrait dengan teknik window lighting tidak ditentukan oleh kecanggihan kamera DSLR, hal ini dibuktikan dengan hasil foto dari dua tipe kamera DSLR Canon 60D yang harganya mahal dengan Canon 1000D, yaitu kamera yang paling murah di tipe DSLR Canon. Penentu hasil akhir tergantung pada kemampuan pemotret dalam memanfaatkan cahaya yang tersedia. Pengaturan kamera dan parameter indokator untuk waktu pemotretan tidak begitu berpengaruh karena menggunakan cahaya yang terbiaskan (inderrect light) sehingga dapat dilakukan dimana saja dan kapan pun selama sesuai dengan indikator yang ditetapkan di atas.

\section{DAFTAR PUSTAKA}

Cassel, Camera Wise Giudes. (1993). Pictures with Secret of Effective Composition, London: Eagelmoss Publication, Ltd, Cassel London. . (1994). Secrets of Light, London: Eagelmoss Publication, Ltd, Cassel London. . (1995) Making The Most of Light, Eagelmoss Publication, Ltd, Cassel London.

Gibrin, Les. (2005). Skill with People. Jakarta: PT. Gramedia Pustaka Utama. . (2009). The Art of Dealing with People. Jakarta: PT. Gramedia Pustaka Utama. 
Levey, Marc. (1980). The Photography Text Book. New York: Watson Guptill Publications.

Peterson, Bryan. (2013). Pintar Exposure. Jakarta: Prigel Books. 